\title{
Treatment Strategies Using Imidacloprid in Hemlock Woolly Adelgid (Adelges tsugae Annand) Infested Eastern Hemlock (Tsuga canadensis Carrière) Trees
}

\author{
Joseph J. Doccola, William Hascher, John Joseph Aiken, and Peter M. Wild
}

\begin{abstract}
Due to the widespread establishment of hemlock woolly adelgid (Adelges tsugae Annand) (HWA) across the range of eastern hemlock (Tsuga canadensis Carriere), woodland trees may be infested for many years before treatment is made. Symptoms of prolonged infestation include extensive dieback and thinned canopies. Imidacloprid, a systemic neonicotinoid insecticide, is a useful and effective tool to manage HWA. In this study, mature, large diameter trees in poor condition were treated with imidacloprid. Trees were treated once by trunk and/or soil injection in Asheville, North Carolina, U.S. Following application, changes in tree growth, HWA density and imidacloprid residues were measured for three years. Trees treated with imidacloprid recovered, whereas the untreated trees continued to struggle. Trees injected with imidacloprid accumulated compound in the canopy, facilitating refoliation and the imidacloprid persisted for three years. This extended activity of trunk-injected imidacloprid was attributed in part to slow upward movement through the restrictive tracheid vascular system and to perennial needle retention. The imidacloprid soil injection was slower to act systemically, but has potential for longer-term activity. Researchers suggest the combination of tree and soil injection for immediate and long-term (4+ years) activity as an effective and economic strategy to protect high-value trees.

Key Words. Eastern Hemlock; Hemlock Woolly Adelgid; Imidacloprid, Soil Injection; Tree Injection.
\end{abstract}

Eastern hemlock (Tsuga canadensis Carrière) covers a wide range of the United States, from New England, New York, Pennsylvania, and the Mid-Atlantic states, expanding westward from central New Jersey to the Appalachian Mountains, and continuing south into northern Georgia and Alabama. In the Midwest, hemlock occurs predominantly in eastern Ohio, northern Michigan, and Wisconsin (USFS). First identified in the early 1950s in Virginia, U.S., hemlock woolly adelgid (Adelges tsugae Annand) (Hemiptera: Adelgidae) (HWA) is an invasive insect that infests hemlock trees. It is considered a pest of Tsuga canadensis Carrière and T. caroliniana Engelmann. The biotype of HWA found in eastern North America genetically matches populations native to the island of Honshu, Japan (Havill et al. 2006). HWA occurs in India, Japan, and China, on four Asiatic species, including T. dumosa Eicher, T. forrestii Downii, and T. chinensis Pritz (Montgomery et al. 2000). Symptoms of HWA infestation include canopy thinning, twig dieback, tree decline, and ultimately death. HWA has spread and now infests approximately half of the eastern native range of hemlock.

Low temperatures may play a role in HWA mortality, thereby limiting its northward spread. Although the cold temperature sensitivity of HWA varies seasonally, substantial mortality occurs at temperatures of $-30^{\circ} \mathrm{C}$ to $-25^{\circ} \mathrm{C}$ (Costa et al. 2004). Such low temperature extremes may occur infrequently, or not at all, in the southern extent of the hemlock range. At least one study suggests that hemlock decline is more rapid in southern Appalachia compared to northern areas (Nuckolls et al. 2009).
HWA has piercing-sucking mouthparts and feeds within the xylem parenchyma cells (McClure 1987) on twigs at the needle base. The xylem parenchyma is living symplast that is rich in carbohydrates and other essential nutrients; as adelgids feed on these food resources, less is available for foliar growth and other essential functions (Shigo 1989). As an infestation progresses, twig lengths decrease, followed by loss of tip growth. McClure (1991) suggested an inverse relationship between HWA population and hemlock growth. This growth loss occurs with increasing HWA pressure and may take three to four years; the impact may be compounded by drought or poor tree vigor. Ward (1991) suggested a threshold of 25-30 HWA/100 needles as negatively impacting twig growth. Doccola et al. (2007) suggest a threshold of $2-4 \mathrm{HWA} / \mathrm{cm}$ twig growth.

McClure (1992) investigated the efficacy of organophosphate insecticide injections and implants for the control of HWA. He reported significant HWA mortality four weeks and five months after treatment. The efficacy of soil injected imidacloprid against HWA has been reported (Steward and Horner 1994; Steward et al. 1998). The translocation of imidacloprid applied to the soil and by trunk injection have been the subject of some investigation (Tattar et al. 1998; Dilling et al. 2010). Tattar et al. (1998) studied three species (Quercus palustris, Tsuga Canadensis, and Pinus strobus), one of each pair receiving soil-applied imidacloprid, the other receiving trunk-injected imidacloprid. Imidacloprid reached lethal concentrations (established at $0.15 \mathrm{ppm}$, the $\mathrm{LC}_{95}$ for Myzus persicae, the peach tree aphid) in one week in $Q$. palustris tree injection compared to eight weeks for soil application, whereas in 
T. canadensis, the $\mathrm{LC}_{95}$ occurred in four weeks and 12 weeks, respectively. Interestingly in $P$. strobus, soil applications reached lethal concentrations in 12 weeks, but tree injected imidacloprid did not reach the $\mathrm{LC}_{95}$ for five months. Dilling reported imidacloprid peaking in T. canadensis 9-12 months following soil applications or tree injections, although none achieved residues of $0.300 \mu \mathrm{g} / \mathrm{g}$, the $\mathrm{LC}_{50}$ for HWA (Cowles et. al. 2006). Trunk injected imidacloprid translocated relatively quickly into the foliage of Ulmus spp. and reduced defoliation by elm leaf beetle, Xanthogalleruca luteola (ELB) (Lawson and Dahlten 2003). The authors suggested that tree injection treatments after sampling egg density offered an advantage over soil-applied treatments that required application in the winter months (presumably when moisture is more available in the area of Sacramento, California, U.S.) for absorption and translocation. Bioassays showed imidacloprid toxicity to ELB larvae at 33 days but not at one year after treatment. Poland et al. (2006) reported rapid translocation of imidacloprid in three host species (Populus nigra, Salix matsudana, and Ulmus pumila) to Asian longhorned beetle, Anoplophora glabripennis, with significant mortality up to nine months after treatment. Leaf and twig residues of imidacloprid ranged from 0.27 to $0.46 \mathrm{ppm}$. Studies in green ash (Fraxinus pennsylvanica Marsh) and white ash ( $F$. americana L.) have reported that imidacloprid accumulates in the canopy from the point of injection and is lost in leaf fall, but suggest that stem injection could provide a reservoir for continued systemic activity (Cregg et al. 2005; Tanis et al. 2006; Tanis et al. 2007; Tanis et al. 2009). Imidacloprid residual activity in hemlock has been investigated and reported (Cowles et al. 2006; Doccola et al. 2007). Cowles et al. (2006) reports that a single soil application of imidacloprid suppresses HWA for $>2$ years. Doccola et al. (2007) reported HWA control following imidacloprid tree injection for two years; however, residues were not conducted in that study. The differences in the time injected hardwoods and conifers accumulate imidacloprid (e.g., Tattar et al. 1998) is consistent with Hagen-Poiseville law which describes the rate of flow as a function of the xylem radius to the fourth power (Kramer et al. 1996). Therefore, hardwoods that have wide vessels (e.g., oaks) move liquid at a faster rate than conifers, which move liquids solely by comparatively narrow tracheids (e.g., hemlocks, pines) (Esau 1977). Even so, there must be an alternative explanation for the slow movement of imidacloprid observed in conifers. The physical chemistry of imidacloprid (e.g., water solubility, affinity to organic carbon) may play a role in its differential movement upward in trees. However, such an investigation is beyond the scope of this paper.

This study focused on imidacloprid treatment efficacy in the southern part of the hemlock range, where HWA has been devastating. Imidacloprid, a neonicotinoid insecticide, is labeled for use and studies have established its efficacy in managing HWA (Steward and Horner 1994; Steward et al. 1998; Webb et al. 2003; Cowles et al. 2006; Doccola et al. 2007). Imidacloprid is available in water soluble packets (WSP), in soluble tablets, or in liquid (SL) formulations, and may be applied to the foliage, soil, or injected directly into the tree. The latter two methods rely on systemic movement of insecticide from the point of application upward into the canopy. Soil and tree-injected formulations are efficiently applied to trees in forested and woodland settings. While spray applications are more commonly used, there may be advantages to combining soil and tree injections for shortterm therapeutic and sustained tree protection in some instances.

The feeding habits of adelgids favor systemic applications. For systemic activity, the insecticide must move upward in the vascular tissues, to concentrate at the growing points at which insects feed. Soil-applied imidacloprid needs to be in solution to be absorbed by tree roots before systemic activity can occur. Trunk-injected imidacloprid is directly introduced into the sapwood for movement upward into the canopy.

Methods of soil application include basal drenches, soil injection, or the use of soluble tablets. The availability of soil-applied imidacloprid (to the tree) depends upon soil moisture, which may be inconsistent in woodland environments. A possible disadvantage to these techniques is their slow action. Imidacloprid applied to soil binds to fine soil particles and to organic matter (organic carbon coefficient, 350) and is slowly dissolved by moisture in the soil (water solubility of imidacloprid is $0.51 \mathrm{~g} /$ Liter) (Cox et al. 1977; EXTOXNET-PIP/Imidacloprid). Soilapplied treatments maintain residual activity over several years (Cowles et al. 2006) and are simple and quick to apply.

Eastern hemlock trees in this study were in poor condition and declining; the trees had thin, sparse foliage and twig dieback. Tree recovery depended on the immediate and sustained adelgid control. Webb et al. (2003) reported that recovery and dramatic new growth of hemlock in poor condition occurred following imidacloprid treatment, although at a slow rate.

Woodland trees depend upon natural rain events for moisture, which could be highly variable. Cruziat et al. (2002) discuss the increase in hydraulic resistance at the soil-root interface during periods of drought and among its consequences: reduced water absorption, conductance, and stomatal closure. Drought was of particular concern because shoot growth, which is critical to tree recovery, depends on adequate soil moisture (Onken 1994), and root uptake of soil-applied imidacloprid depends on it being dissolved (i.e., available) in the soil solution.

The study objectives were to evaluate tree responses to different methods and rates of imidacloprid application and to evaluate the extent of residual activity of the treatments. To evaluate the effectiveness of the techniques, assessments were conducted on HWA density and twig growth, and imidacloprid was extracted from hemlock needles for three years.

\section{MATERIALS AND METHODS}

\section{Study Site}

Eastern hemlock (Tsuga canadensis) trees were selected for treatment: large diameter, mature trees $\sim 30$ meters in height located on the Biltmore Estate in Asheville, North Carolina, U.S. (latitude: $35.567^{\circ} \mathrm{N}$, longitude: $-82.5448^{\circ} \mathrm{W}$ ). Treatments were assigned at random in two blocks. In poor condition and declining, the trees had thin, sparse foliage with tips dying back. The trees had $\sim 25 \%$ live crown ratio, and ranged from 26.5 to 86.8 $\mathrm{cm}$ diameter at breast height $(\mathrm{DBH})$ with a mean $\mathrm{DBH}$ of $49 \mathrm{~cm}$.

\section{Application Techniques}

Forty-eight hemlocks were treated with insecticide formulations containing the active ingredient imidacloprid (1-[(6-chloro-3-pyridinyl) methyl]-N-nitro-2-imidazolidinimine) for HWA 
infestations. Six treatments were assigned in two randomized blocks, each of which was replicated eight times. The treatments were (1) untreated controls (UTC), (2) IMA-jet [5\% (g/g) imidacloprid SL systemic insecticide; Arborjet, Inc., Woburn, Massachusetts, U.S.] low rate, (3) IMA-jet high rate, (4) IMA-jet low + Merit ${ }^{\circledR} 75$ WSP $[75 \%$ (g/g) imidacloprid; Bayer Environmental Science, Research Triangle Park, North Carolina, U.S.] soil injection, (5) IMA-jet high + Merit soil injection, and (6) Merit soil injection alone. Soil injections were made using the Kioritz ${ }^{\circledast}(\mathrm{Ki}-$ oritz Corporation, 7-2, Suehirocho 1 -Chome, Ohme, Tokyo, 198 Japan) injector; applications were made 30-90 cm away from the tree bole, where the fibrous roots were most likely concentrated. Each Merit 75 WSP $45.4 \mathrm{~g}$ packet was mixed in $960 \mathrm{ml}$ of water, per label instructions. The Arborjet ${ }^{\circledR}$ Tree I.V. and the QUIK-jet ${ }^{\circledR}$ injector were used to make the tree injections. Low rates of imidacloprid were applied at $0.15 \mathrm{~g}$ a.i. $/ 2.5 \mathrm{~cm} \mathrm{DBH}$, high rates were applied at $0.30 \mathrm{~g}$ a.i. $/ 2.5 \mathrm{~cm} \mathrm{DBH}$, and soil injections were made at $1.45 \mathrm{~g}$ a.i. $/ 2.5 \mathrm{~cm} \mathrm{DBH}$. QUIK-jet injections applied $3 \mathrm{ml}$ IMA-jet per $2.5 \mathrm{~cm} \mathrm{DBH}$ and the TREE I.V. applied $6 \mathrm{ml}$ IMA-jet per $2.5 \mathrm{~cm} \mathrm{DBH}$. For example, in a $50 \mathrm{~cm}$ DBH tree, 60 and $120 \mathrm{ml}$ of IMA-jet were applied for low and high dose injections, respectively. The IMA-jet formulation was applied at rates lower than the 4 to $8 \mathrm{ml}(0.2$ to $0.4 \mathrm{~g})$ a.i. $/ 2.5$ $\mathrm{cm}$ DBH label use recommendations. Tree injections of imidacloprid were applied as formulated. The injection site was made into the trunk flare (i.e., basally) using a $9 \mathrm{~mm}$ Brad point bit, drilled $3.75 \mathrm{~cm}$ into the sapwood and fitted with an Arborplug ${ }^{\mathrm{TM}}$ (a backflow prevention device) to create a $2.5 \mathrm{~cm}^{3}$ capacity site to mitigate for slow uptake in the sapwood tracheids. The number of application sites varied from 15 to $20 \mathrm{~cm}$ of stem circumference for the QUIK-jet and Tree I.V., respectively. Treatments were applied on August 29-30, 2007 at the Biltmore Estate. The imidacloprid treatments were timed to coordinate with the resumption of adelgid activity following summer aestivation. The amount of time for each treatment to be applied was recorded.

\section{Tree Assessments}

Branch samples were taken from trees each November from 2007 to 2010 (at approximately $70,435,800$, and 1,165 days after treatment) for assessment and imidacloprid residues (Table 1). Autumn was selected for sampling because tree growth was expected to be complete, HWA resumed development following summer aestivation (therefore were easier to assay), and before low temperature events could adversely affect HWA survival. Four branches were cut, each between 40 and $60 \mathrm{~cm}$ in length, from the mid-tree canopy in four sectors by aerial lift truck, and shipped to Arborjet, Inc. for evaluation. Branches were refrigerated at $4.4^{\circ} \mathrm{C}$ until the assessments were conducted. Digital scans were made of all of the branch samples, using a Canon Color Image Scanner (CanoScan $8800 \mathrm{~F}$ ); the digital images captured the temporal changes in tree condition. Percent tip growth was estimated for each branch sampled, and the mean calculated for each tree. Tip growth was determined on a percentage basis, adapting the method by Webb et al. (2003). Within a treatment, percentage of branches with new tip growth was determined by dividing the number of tips with new growth by the total tips counted, multiplied by 100. Each branch was then cut into five shorter branchlets (terminal, plus four laterals) to evaluate the number of HWA per $\mathrm{cm}$ of new growth. HWA infestations were assessed by microscopic examination. The number of HWA on twigs with needles was counted, branch length was measured, and the value HWA /cm was calculated.

Table 1. Treatments, imidacloprid residues in $\mu \mathrm{g} / \mathrm{g}(\mathrm{ppm})$, percent tip growth, and HWA infestation per centimeter of branch. The $\mathrm{LC}_{50}$ value for HWA is $0.30 \mu \mathrm{g} / \mathrm{g}$ (Cowles et al. 2006). Per treatment, percent tip growth is a measure of the mean number of tips on branches with new growth.

\begin{tabular}{|c|c|c|c|c|}
\hline Year & Treatment & $\mu \mathrm{g} / \mathrm{g}$ & $\%$ Tip growth & $\mathrm{HWA} / \mathrm{cm}$ \\
\hline \multirow[t]{6}{*}{2007} & Untreated controls & $0.01^{z}$ & $5.60 \mathrm{~b}$ & $0.28 b$ \\
\hline & IMA-jet Lo & $0.20 \mathrm{a}$ & $6.07 \mathrm{~b}$ & $0.17 b$ \\
\hline & IMA-jet Hi & $0.17 \mathrm{a}$ & $3.41 \mathrm{~b}$ & $0.00 \mathrm{~b}$ \\
\hline & IMA Lo + imidacloprid soil & $0.22 \mathrm{a}$ & $13.04 \mathrm{~b}$ & $0.21 \mathrm{~b}$ \\
\hline & IMA Hi + imidacloprid soil & $0.86 \mathrm{a}$ & $7.74 b$ & $0.00 \mathrm{~b}$ \\
\hline & MERIT soil & $0.14 \mathrm{a}$ & $1.62 \mathrm{~b}$ & $0.11 b$ \\
\hline \multirow[t]{6}{*}{2008} & Untreated controls & $0.02^{z}$ & $2.59 \mathrm{~b}$ & $1.80 \mathrm{~b}$ \\
\hline & IMA-jet Lo & $1.75 \mathrm{ac}$ & $12.54 \mathrm{~b}$ & $1.82 b$ \\
\hline & IMA-jet Hi & $3.79 \mathrm{a}$ & $19.60 \mathrm{~b}$ & $0.38 b$ \\
\hline & IMA Lo + imidacloprid soil & $1.32 \mathrm{abc}$ & $30.58 \mathrm{a}$ & $0.92 b$ \\
\hline & IMA Hi + imidacloprid soil & $3.27 \mathrm{a}$ & $33.57 \mathrm{a}$ & $0.72 b$ \\
\hline & MERIT soil & $0.33 b$ & $2.61 \mathrm{~b}$ & $2.81 \mathrm{~b}$ \\
\hline \multirow[t]{5}{*}{2009} & Untreated controls & $0.09^{z}$ & $36.90 \mathrm{~b}$ & $1.42 \mathrm{~b}$ \\
\hline & IMA-jet Lo & $2.04 b$ & $72.27 \mathrm{a}$ & $0.04 \mathrm{a}$ \\
\hline & IMA-jet Hi & $3.61 \mathrm{ab}$ & $70.29 a$ & $0.08 \mathrm{a}$ \\
\hline & IMA Lo + imidacloprid soil & $3.70 \mathrm{ab}$ & $81.70 \mathrm{a}$ & $0.03 \mathrm{a}$ \\
\hline & IMA Hi + imidacloprid soil & $6.54 \mathrm{a}$ & $79.77 \mathrm{a}$ & $0.03 \mathrm{a}$ \\
\hline \multirow[t]{6}{*}{2010} & Untreated controls & $0.15^{z}$ & $48.51 b$ & $1.79 \mathrm{c}$ \\
\hline & IMA-jet Lo & $1.35 b$ & $90.01 \mathrm{a}$ & $0.12 \mathrm{a}$ \\
\hline & IMA-jet Hi & $1.83 b$ & $84.64 a$ & $0.19 \mathrm{a}$ \\
\hline & IMA Lo + imidacloprid soil & $3.54 \mathrm{ab}$ & $90.01 \mathrm{a}$ & $0.00 \mathrm{a}$ \\
\hline & IMA Hi + imidacloprid soil & $4.76 \mathrm{a}$ & $90.01 \mathrm{a}$ & $0.00 \mathrm{a}$ \\
\hline & MERIT soil & $2.37 \mathrm{ab}$ & $60.20 b$ & $0.26 b$ \\
\hline
\end{tabular}

Notes: $\mathrm{n}=8$. Means followed by the same letter are not significantly different at $P<0.05$. Percentage data transformed (asin (sqrt (x/100)) *57.3 prior to ANOVA. Actual means are presented in table.

${ }^{\mathrm{z}}$ Not included in statistical analyses $(\mathrm{n}<8)$. 


\section{Imidacloprid Residues}

Five additional branchlet samples from each of the four branches were combined, generating $\sim 25 \mathrm{~g}$ of hemlock foliage for imidacloprid residues. The foliage was placed into plastic bags, and stored at $-18^{\circ} \mathrm{C}$ until imidacloprid residues were run. Foliage was sent out to independent labs for residue testing. Foliage sent to Bayer Environmental Science determined the 2007-2008 imidacloprid residues; the USDA FS (Pineville, Louisiana, U.S.) conducted the 2009-2010 imidacloprid residues. Samples sent to Bayer were ground in liquid nitrogen and extracted using a modified QuEChERS procedure prior to HPLC-MS/MS analysis (Lehotay et al. 2010). Imidacloprid metabolites that have insecticidal activity include olefinic-, dihydroxy-, and hydroxy-imidacloprid (Sangha and Machemer 1992; Suchail et al. 2001). Imidacloprid, imidacloprid-olefin, and 5-OH imidacloprid residues were reported. Each sample was analyzed in duplicate, and the mean reported. Hemlock foliage sent for the 2009-2010 analyses conducted by the USDA FS were dried, ground in a Wiley mill prior to solvent extraction. For extraction, $1 \mathrm{~g}$ of dried hemlock foliage was placed in a $15 \mathrm{ml}$ vial to which $10 \mathrm{ml}$ of methanol was added, and the vial was agitated overnight on a shaker table. The sample was allowed to settle and supernatant drawn for ELISA analyses (Fischer et al. 2009). Polyclonal ELISA (EnviroLogix ${ }^{\mathrm{TM}}$; Portland, Maine, U.S.) kit was used in these analyses. Plate absorbance was read using a Biotek ELx808 plate reader (Biotek, Inc., Winooski, Vermont, U.S.) and results calculated using Biotek Gen5 software. Samples outside specified calibration of $>6.0 \mathrm{ppb}$ were diluted with deionized water and reanalyzed. Each sample was analyzed in duplicate, and the mean was reported. These (HPLC and ELISA) methods are similar; however the ELISA method is semiquantitative for imidacloprid and will overestimate imidacloprid because reported residues include imidacloprid plus metabolites (Montfort et al. 1994; Fischer et al. 2009; Frank Byrne pers. comm.). Researchers report the "imidacloprid plus metabolites" of the HPLC and ELISA analyses as imidacloprid residues for the purposes of comparison. Two or three untreated hemlock samples were used for residue analyses and were therefore excluded from statistical analyses. For imidacloprid efficacy, researchers used the published $\mathrm{LC}_{50}$ for HWA of $0.300 \mu \mathrm{g} / \mathrm{g}$ (Cowles et al. 2006) as a reference value. The means are presented in Table 1.

\section{Precipitation Data}

Onken (1994, unpublished data) reported a direct relationship between the amount of rainfall that trees receive in a given year and the amount of new growth in the following year. Monthly weather summaries were obtained from online data provided by the National Weather Service Forecast Office, Greenville-Spartanburg, South Carolina, U.S. (NOAA), $\sim 80 \mathrm{~km}$ from the study site. Monthly total precipitation from 2006 to 2009 was compared to the norm (average).

\section{Statistical Analyses}

Data were transformed before carrying out analysis of variance (ANOVA) in order to achieve approximate homogeneity of variances across treatments. The arcsine transformation was applied to the proportion of terminals showing growth. A log transformation was applied to $\mathrm{HWA} / \mathrm{cm}$ and imidacloprid residues, the specific transformations being $\log (\mathrm{HWA}$ _cm +0.005$)$ and $\log ($ Residue $+0.05)$, respectively, due to 0 values for each measurement.
A repeated ANOVA was performed using Proc Mixed (SAS, Inc., Cary, North Carolina, U.S.) on the data across years for each of the three (transformed) responses. The fixed effects in the model were Block, Treatment, Year, and Treatment*Year interaction. Based on preliminary analyses, Block*Treatment was included as an additional fixed effect for LogHWA only. To allow for serial correlations and heterogeneity of variances across years, the error covariance was assumed to be a first-order heterogeneous autoregressive structure using the REPEATED statement with option ARH(1). Comparisons among treatment means averaged over years were performed if the Treatment*Year interaction was not important. If interaction was statistically significant and biologically important, treatment comparisons were carried out separately for each year (in MINITAB Version 15, Minitab, Inc., State College, Pennsylvania, U.S.). Comparisons were carried out using the protected LSD procedure at significance level 0.05. Trend analyses were plotted for each imidacloprid treatment applying a quadratic trend model, which was the best fit for the residue data.

\section{RESULTS}

The amount of time needed to make an application varied with the method used, although all three methods were relatively efficient. Mean application times were 2, 5, and 10 minutes for the QUIK-jet, Kioritz, and Tree I.V., respectively.

\section{Growth}

Digital scans from 2007 to 2010 documented the temporal changes in tree condition (Figures 1). Year effects were highly significant $(\mathrm{F}=231.24, \mathrm{DF}=3,126, P<0.001)$ reflecting an increase in growth over time for all treatments. Treatment and Year*Treatment interaction were both significant $(\mathrm{F}=10.02, \mathrm{DF}=5,41, P<$ 0.001 and $\mathrm{F}=3.02, \mathrm{DF}=15,126, P<0.001$, respectively). A graph of treatment means against year showed that trends were roughly similar across treatments except that the rate of increase was slower for the UTC and soil alone treatments, thus treatments comparisons are based on means across years (Table 1; Figure 2).

\section{Log HWA}

Treatment, Year and Treatment*Year interaction were all significant $(\mathrm{F}=9.46, \mathrm{DF}=12.49, P<0.001 ; \mathrm{F}=12.49, \mathrm{DF}=3,126$, $P<0.001$; and $\mathrm{F}=2.14$, DF $=15,126, P=0.011$, respectively). Block and Block*Treatment effects were also significant $(\mathrm{F}$ $=16.01, \mathrm{DF}=1,36, P<0.001$ and $\mathrm{F}=5.28, \mathrm{DF}=5,36, P$ $=0.001$, respectively) mainly because of some high values for soil treatment in Block II. Trends across years are similar for the treatments 2-5 (tree injections $+/$ - soil), but different from UTC and imidacloprid soil treatment, so treatment comparisons are reported separately for each year (Table 1). Means of $\mathrm{HWA} / \mathrm{cm}$ across years for treatments are presented in Figure 3.

\section{Log Residue}

Year effects are highly significant $(\mathrm{F}=147.36, \mathrm{DF}=3,105, P<$ $0.001)$, Treatment and Treatment*Year interaction are also significant $(\mathrm{F}=12.52, \mathrm{DF}=4,34, P<0.001$ and $\mathrm{F}=7.38$, DF $=12,105, P<0.001$, respectively). Trends across years were not consistent across treatments and treatment comparisons are reported separately for each year (Table 1). Means for imidacloprid residues for 70 to 1165 DAT are presented in Figure 4. 


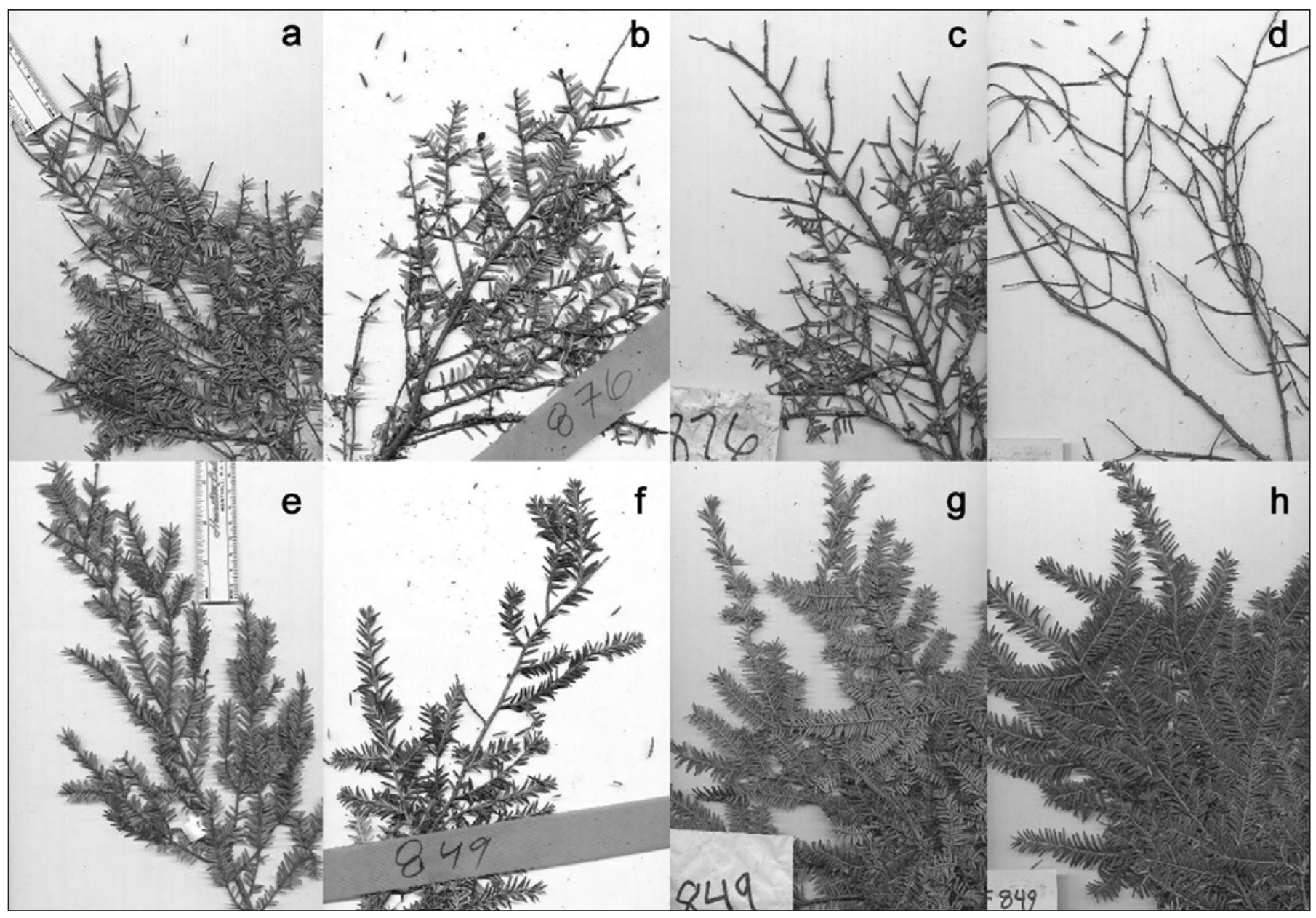

Figure 1. Digital scans of hemlock terminals comparing the temporal changes in untreated control to the imidacloprid treatment from 2007 to 2010. From top left, untreated tree showing symptoms of $(a, b)$ thinned foliage, (c) dieback/decline, and (d) branch death. From bottom left, of imidacloprid tree and soil injection treatment with (e) thinned foliage and of recovery, (f-h) and progressive twig growth and refoliation.

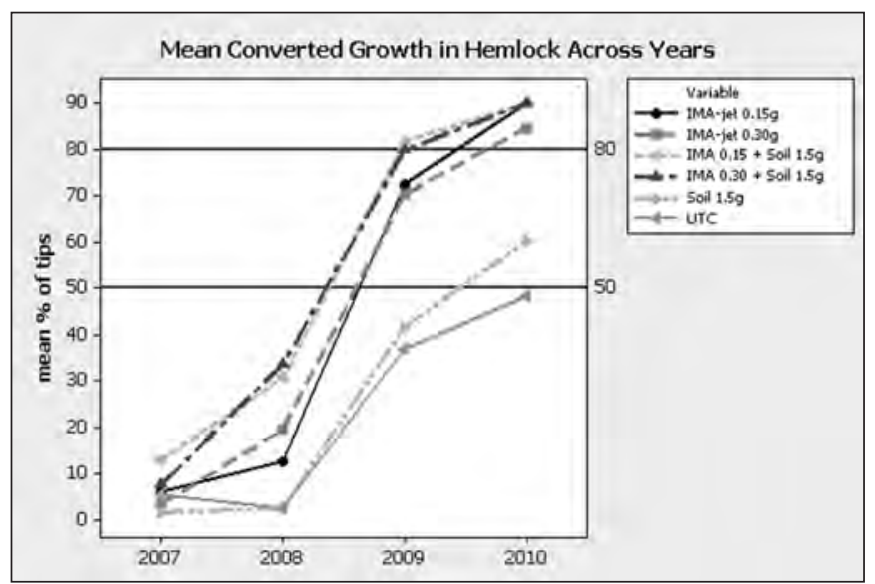

Figure 2. Mean percentage of growing tips (converted) in hemlock across the years. At the start of the study, $<13.0 \%$ of trees had new growth, reflecting the poor condition of the trees. Recovery was observed over the course of the study, where injected trees (+/-soil injection) refoliated at faster rates than the soil alone treatment or the untreated trees. Mean refoliation three years after treatment for the injected trees (+/-soil injection), soil injection, and untreated was $>84.6 \%, 60.2 \%$, and $48.5 \%$, respectively.

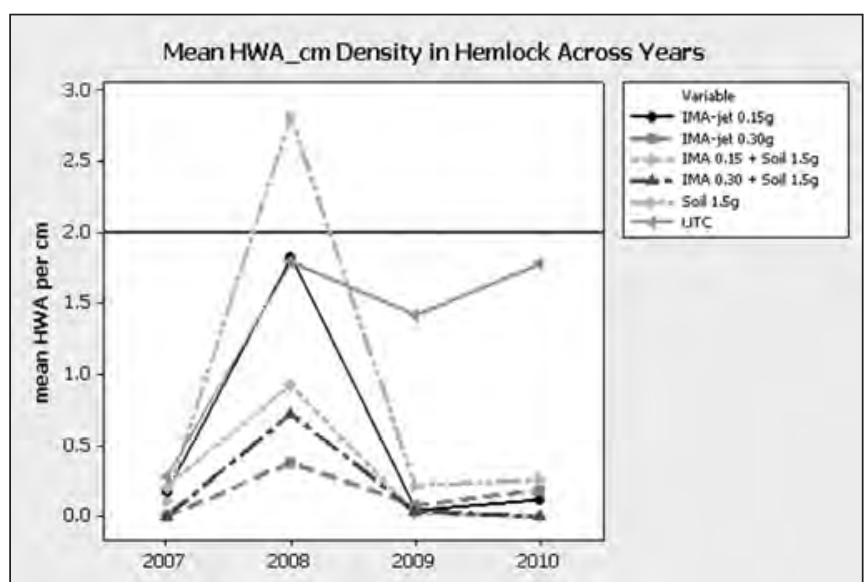

Figure 3. Mean HWA/cm on new foliage of hemlock across years. At the start of the study, adelgid numbers were low, a result of dieback in trees from the previous years of infestation. As trees put on new foliage, the adelgid populations rebounded and in 2008 approached densities (of $2.0 \mathrm{HWA} / \mathrm{cm}$ ) that negatively impact hemlock growth. In the subsequent years, HWA collapsed in the imidacloprid treatments, but persisted in the untreated trees. 


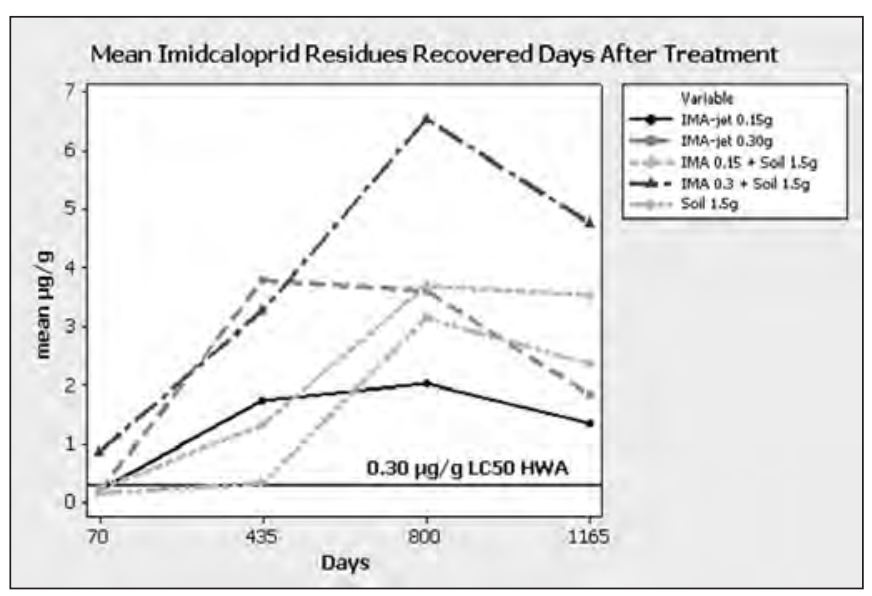

Figure 4. Concentrations of imidacloprid in $\mu \mathrm{g} / \mathrm{g}$ in hemlock needles $70,435,800$, and 1165 days after treatment. Tree injected imidacloprid accumulated in the canopy at a faster rate compared to the soil injection treatment. Imidacloprid residues in the trunk injected (+/-soil injection) treated trees were consistently above the $\mathrm{LC}_{50}$ value $($ of $0.30 \mu \mathrm{g} / \mathrm{g})$ for HWA in the three years studied.

\section{Monthly Precipitation}

The monthly mean precipitation for Asheville, NC, is $9.81 \mathrm{~cm}$. The 2006 mean monthly precipitation for Asheville $(10.06 \mathrm{~cm})$ was not significantly different from the normal value, and adequate for hemlock growth in the subsequent year. However, poor growth was observed in 2007. The 2007 mean monthly precipitation was significantly below normal $(7.16 \mathrm{~cm}, \mathrm{p}=0.015)$, which could have played a role in the limited refoliation observed in 2008. The monthly precipitation in 2008 was below normal, but was not statistically significant $(7.42 \mathrm{~cm}, \mathrm{p}=0.068)$. Below normal rainfall in 2008 was probably not a factor in limiting tree growth in 2009. Precipitation in 2009 was not significantly different from normal, and did not appear to limit growth in hemlock in 2010.

\section{Analysis of Imidacloprid Residues}

Imidacloprid residues were extracted from hemlock needles 70, 435, 800, and 1165 days after treatment. These results are

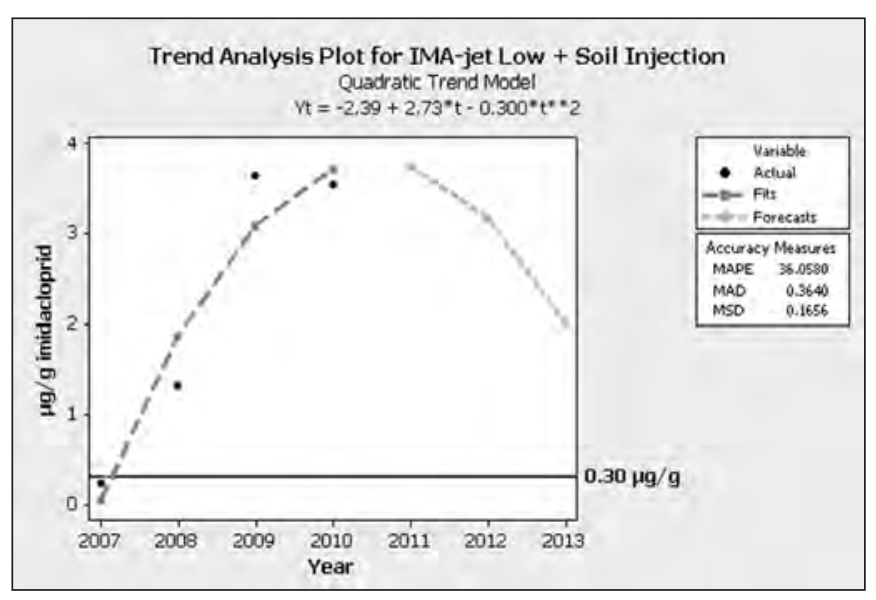

Figure 5. IMA-jet low + imidacloprid soil injection actual $\mu \mathrm{g} / \mathrm{g}$ imidacloprid with forecast trend to 2013. This model plots residues above the LC $C_{50}$ HWA of $0.30 \mu \mathrm{g} / \mathrm{g}$ through 2013, six years following treatment. presented in Table 1 and in Figure 4 in $\mu \mathrm{g}$ of compound per gram of dried needles (i.e., ppm). Trunk injected imidacloprid accumulated more rapidly (1 year) into the canopy compared to soil-applied only imidacloprid. Although soil-applied imidacloprid accumulated more slowly (two years) in the canopy, it may persist longer. Forecast plots were conducted to predict imidacloprid residues beyond three years following treatments. Trend plot analysis for tree injection low dose (quadratic equation, $\mathrm{Yt}=-2.4+$ $3.174 * \mathrm{t}-0.56 * \mathrm{t} * 2)$ forecasted residues $>0.300 \mu \mathrm{g} / \mathrm{g}\left(\mathrm{LC}_{50}\right.$ for HWA) to four years following treatment, while tree injection + soil injection (Figure 5) and soil injection alone (quadratic equation, $\mathrm{Yt}=-2.39+2.73 * \mathrm{t}-0.300 * \mathrm{t} * 2$, and $\mathrm{Yt}=-1.83+1.83 * \mathrm{t}-0.155 * \mathrm{t} * 2$, respectively) forecasts residues $>0.300 \mu \mathrm{g} / \mathrm{g}$ to six years following treatment.

\section{CONCLUSIONS AND DISCUSSION}

The study authors examined HWA-infested trees in the southern part of the hemlock range and collected data on foliage growth, HWA density, and imidacloprid residues for three years. At the time of treatment in 2007, the hemlocks had thinned canopies and significant dieback: $51.6 \%$ of the trees were in decline. Only $17.1 \%$ of the branch samples collected had enough foliage to conduct an analysis of adelgid activity, from which the adelgid numbers were low. Terminal dieback and low adelgid density indicated a protracted infestation, leaving the stand in poor condition. The trees were treated in late summer to coordinate with the resumption of HWA feeding. Low levels of imidacloprid were recovered from needles of trees treated at 70 days. However, significant growth responses to treatment would not be observed for two years. Translocation upward was likely slowed by sparse canopies and reduced transpiration potential.

As trees refoliated, adelgid density was observed to increase. Three of the treatments (though not statistically significant) had mean adelgid densities that were approximately great enough $(\sim 2.0 \mathrm{HWA} / \mathrm{cm})$ to impact hemlock growth, pointing to a need for continued protection. While adelgid density remained high across the years 2008-2010 in the untreated trees, their numbers dropped to negligible levels in the imidacloprid treatments at 800 days and remained so at 1165 days (Figure 3 ), supporting insecticidal efficacy and residual activity. Imidacloprid residues exceeded the $\mathrm{LC}_{50}$ value for HWA in each analysis conducted after 70 days (Figure 4). The treatments with the highest residues (tree injection $+/$ - soil treatments) at 435 days and 800 days were associated with statistically significant growth in subsequent years (2009 and 2010, respectively). In addition to insecticidal activity, imidacloprid may have played a direct role in aiding refoliation (Chiriboga 2009). Tree responses were positive, but slow, consistent with that reported by Webb et al. (2003), the greatest growth occurred in the second year following treatment (Table 1; Figure 2).

The study authors observed a comparatively slower initial rate of accumulation of residues from the soil alone treatment. Relatively dry soil conditions (in 2007, 2008) may have accounted for the low imidacloprid residues obtained in the first two years studied. Imidacloprid is absorbed by roots when it is dissolved in the soil solution. The sparse trees showed signs of recovery when imidacloprid systemic activity occurred. Though mean residues were $\geq \mathrm{LC}_{50}$ for HWA in 2008, HWA/ 
cm (2.81) likely limited refoliation. Residues increased in $2009(3.14 \mu \mathrm{g} / \mathrm{g})$ and adelgid density dropped and remained low; percent tip growth in 2010 showed signs of recovery.

The observation of imidacloprid accumulation (in the injected hemlocks) over time may be explained by its slow upward movement from stem to foliage. It is conceivable that the imidacloprid is stored within the xylem axial and radial parenchyma (living symplast) in the tree, or that its slow upward movement is related to binding to cellulose (the non-living apoplast), particularly in the minute conifer tracheids. Xylem cellulose is $44 \%$ carbon (Heukelekian and Waksman 1925), constituting an extensive adsorptive surface. The carbon adsorption coefficient of imidacloprid is $\sim 350$, which suggests moderate adhesion in the xylem (Cox et al., 1977). Whatever the precise mechanism (symplast absorption or apoplast adsorption), systemic application of imidacloprid in an evergreen tree is retained and/or accumulates over the leaf's lifespan. In Eastern hemlock needles are retained perennially (i.e., from three to six years) (Ford and Vose 2006). This observation has implications on extending the insecticide application interval.

Forecast plots were conducted to predict imidacloprid residues in hemlock over time, which suggest sustained activity against HWA from a single treatment of imidacloprid for a period of four to six years. These data suggest that the low rates of tree injected imidacloprid could be administered once every three to four years to protect woodland trees. High rate injection or the one-two strategy (of tree and soil injection) may afford longer (six years) term protection of hemlock. Early systemic activity and extended re-treatment cycles are attractive from both efficacy and economic standpoints, particularly if large numbers of trees require treatment.

Acknowledgements. The authors gratefully acknowledge Royce Clay, Arborist for the Biltmore Estate for providing the annual samples needed to conduct the assays, and the support of Reed N. Royalty, Insecticide Product Development Manager, Bayer Environmental Science (Clayton, $\mathrm{NC}$ ) for providing the Merit $75 \mathrm{WSP}$ for the study and for supporting the imidacloprid residue analyses. The authors also thank Brenda I. Cruz for assistance in conducting the hemlock assessments. The authors thank Joe Fischer and Brian L. Strom, USFS Southern Research Station (Pineville, LA) for conducting the ELISA analyses, and to Cavell Brownie, Professor Emeritus, North Carolina State University (Raleigh, NC) for conducting the RM statistical analyses.

\section{LITERATURE CITED}

Chiriboga, C.A. 2009. Physiological responses of woody plants to imidacloprid formulations. M.S. Thesis. Ohio State University. Columbus, Ohio, U.S. 146 pp.

Cowles, R.S., M.E. Montgomery, and C.A.S-J. Cheah. 2006. Activity and residues of imidacloprid applied to soil and tree trunks to control hemlock woolly adelgid (Hemiptera: Adelgidae) in forests. Journal of Economic Entomology 99:1258-1267.

Costa, S.D., M. Skinner, and B. L. Parker. 2004. HWA cold-hardiness: towards defining limits of range expansion. In: Proceedings, XV USDA Intragency Research Forum on Gypsy Moth and Other Invasive Species. GTR-NE-322. pp. 19-22.

Cox, L., W.C. Koskinen and P.Y. Yen. 1997. Sorption-desorption of imidacloprid and its metabolites in soils. Journal of Agricultural and Food Chemistry 45:1468-1472.

Cregg, B.D., Mota-Sanchez, D. McCullough, R. Hollingworth, and T. Poland. 2005. Distribution and persistence of trunk-injected ${ }^{14} \mathrm{C}$ imi- dacloprid in ash trees. In: Emerald Ash Borer Research and Technology Development Meeting. September 26-27, 2005. FHTET-2005-16. pp. 24-25.

Cruziat, P., H. Cochard, and T. Ameglio. 2002. Hydraulic architecture of trees: Main concepts and results. Annals of Forestry Science 59:723-752.

Dilling, C., P. Lambdin, J. Grant, and R. Rhea. 2010. Spatial and temporal distribution of imidacloprid in eastern hemlock in the southern Appalachians. Journal of Economic Entomology 103:368-373.

Doccola, J., E. Bristol, S. Sifleet, J. Lojko, and P. Wild. 2007. Efficacy of trunk-injected imidacloprid in the management of hemlock woolly adelgid (Adelges tsugae). Arboriculture \& Urban Forestry 33:12-21.

Esau, K. 1977. The Anatomy of Seed Plants. Second Edition. John Wiley and Sons. New York, New York, U.S. 550 pp.

EXTOXNET. Extension Toxicology Network. Pesticide Information Profiles. IMIDACLOPRID. Accessed 1/14/2010. <http://extoxnet. orst.edu/pips/imidaclo.htm>

Fischer, J., B. Strom, and S. Smith. 2009. Evaluation of a commercially available ELISA kit for quantifying residues in Erythrina sandwicensis leaves for management of the Erythrina gall wasp, Quadrastichus erythrinae Kim. Pan-Pac. Entomol. 85:99-103.

Ford, C., and J. Vose. 2006. Eastern hemlock transpiration: Patterns, controls, and implications for its decline in southern Appalachian forests. In Second Interagency Conference on Research in the Watersheds. May 16-18, 2006. USDA ARS. Coweeta Hydrologic Laboratory. 8 pp.

Havill, N. P., M.E. Montgomery, G. Yu, S. Shiyake, and A. Caccone. 2006. Mitochondrial DNA from hemlock woolly adelgid (Hemiptera: Adelgiddae) suggest cryptic separation and pinpoints the source of the introduction to eastern North America. Annals of Entomology Society of America 99:195-203.

Heukelekian, H., and S.A. Waksman. 1925. Carbon and nitrogen transformations in the decomposition of cellulose by filamentous fungi. Journal of Biological Chemistry 66:323-342.

Kramer, P.J., S.G. Pallardy, and T.T. Kozlowski. 1996. Physiology of Woody Plants. Second Edition. Academic Press. 411 pp.

Lawson, A.B., and D.L. Dahlten. 2003. Evaluation of systemic insecticides as a treatment option in integrated pest management of the elm leaf beetle, Xanthogalleruca luteola (Müller) (Coleoptera: Chrysomelidae). Journal of Economic Entomology 96:1455-1462.

Lehotay, S.J., K.A. Son, H. Kwon, U. Koesukwiwat, W. Fu, K. Mastrovska, E. Hoh, and N. Leepipatpiboon. 2010. Comparison of QuEChERS sample preparation methods for the analysis of pesticide residues in fruits and vegetables. Journal of Chromatography A 1217:2548-2560.

McClure, M.S. 1987. Biology and control of hemlock woolly adelgid. Bull. Conn. Agric. Exp. Stn. 851.

McClure, M.S. 1991. Density-dependent feedback and population cycles in Adelges tsugae (Homoptera: Adelgidae) on Tsuga canadensis. Environmental Entomology 20:258-264.

McClure, M.S. 1992. Effects of implanted and injected pesticides and fertilizers on the survival of Adelges tsugae (Homoptera: Adelgidae) and on the growth of Tsuga canadensis. Journal of Economic Entomology 85:468-472.

Montfort, K.A., S.L. Reynolds, S.A. Thorpe, and S.N. White. 1994. Comparison of ELISA and HPLC techniques for the analysis of carbendazim and thiabendazole residues in fruit and vegetables. Food and Agriculture Immunology 6:17-22.

Montgomery, M.E., D. Yao, and H. Wang. 2000. Chinese Coccinellidae for biological control of the hemlock woolly adelgid: description of native habitat. Proceedings: Symposium in Sustainable Management of Hemlock Ecosystems in Eastern North America. GTR-NE-267. pp. 97-102. 
NOAA. National Weather Service Forecast Office. Greenville-Spartansburg, S.C. Weather Reports. Monthly Weather Summary (CLM). Webpage. Accessed 01/07/2007-01/14/2010. <www.weather.gov/climate/index. php?who=gsp $>$.

Nuckolls, A., N. Wurzburger, C. Ford, R. Hendrick, J. Vose, and B. Kloeppel. 2009. Hemlock declines rapidly with hemlock woolly adelgid infestation: Impacts on the carbon cycle of southern Appalachian forests. Ecosystems 12:179-190.

Onken, B.P. 1994. A summary of impacts from HWA and drought on eastern hemlocks in New Jersey. Unpublished Data. USDA-FS, Morgantown, WV. Phillip Alampi Beneficial Insect Laboratory, Division of Plant Industry, New Jersey Department of Agriculture.

Poland, T.M., R.A. Haack, T.R. Petrice, D.L. Miller, L.S. Bauer, and R. Gao. 2006. Field evaluations of systemic insecticides for control of Anoplohora glabripennis (Coleoptera: Cerambycidae) in China. Journal of Economic Entomology 99:383-392.

Sangha, G., and L. Machemer. 1992. An overview of the toxicology of NTN 33893 and its metabolites. Unpublished study prepared by Miles, Inc. 134 pp. In: SERA (Syracuse Environmental Research Associates, Inc.). 2005. Imidacloprid - human health and ecological risk assessment - final report. SERA TR 05-43-24-03a. 283 pp.

Shigo, A. 1989. A new tree biology: Facts, photos, and philosophies on trees and their problems and proper care. Second Edition. Shigo and Trees Associates. Durham, New Hampshire, U.S. 618 pp.

Steward, V.B., and T.A. Horner. 1994. Control of hemlock woolly adelgid using soil injections of systemic insecticides. Journal of Arboriculture 20:287-288

Steward, V.B., G. Braness, and S. Gill. 1998. Ornamental pest management using imidacloprid applied with the Kioritz soil injector. Journal of Arboriculture 20:344-346.

Suchail, S., D. Guez and L.P. Belzunces. 2001. Discrepancy between acute and chronic toxicity induced by imidacloprid and its metabolites in Apis mellifera. Environmental Toxicology and Chemistry 20:2482-2486.

Tanis, S., B. Cregg, D. Mota-Sanchez, D. McCullough, T. Poland and R. Hollingworth. 2006. Distribution of trunk-injected ${ }^{14} \mathrm{C}$ imidacloprid in Fraxinus trees: A test of the sectored-flow hypothesis. In Emerald Ash Borer Research and Technology Development Meeting. October 29 - November 2, 2006. FHTET-2007-04. pp. 34-38.

Tanis, S., B. Cregg, D. Mota-Sanchez, D. McCullough, T. Poland, and R. Hollingworth. 2007. Sectored flow and reservoirs: a synthesis of 14C-imidacloprid trunk injection research. In: Emerald Ash Borer Research and Technology Development Meeting. October 23-24, 2007. FHTET-2008-07. pp. 45-47.
Tanis, S., B. Cregg, D. Mota-Sanchez, D. McCullough, and T. Poland. 2009. Sectored flow and reservoirs: a synthesis of ${ }^{14} \mathrm{C}$-imidacloprid trunk injection research. In: Emerald Ash Borer Research and Technology Development Meeting. October 20-21, 2009. FHTET-2010-01. pp. 79-80.

Tattar, T.A., J.A. Dotson, M.S. Ruizzo, and V.B. Steward. 1998. Translocation of imidacloprid in three species when trunk and soil injected. Journal of Arboriculture 24:54-56.

USFS. Silvics Manual. Volume 1. Tsuga canadensis. Accessed 1/14/2010.<http://na.fs.fed.us/pubs/silvics_manual/Volume_1/tsuga/ canadensis.htm >

Ward, R. 1991. The effect of the hemlock woolly adelgid Adelges tsugae (Homoptera: Adelgidae) in New Jersey forests. Unpublished, Phillip Alampi Beneficial Insect Laboratory, Division of Plant Industry, New Jersey Department of Agriculture.

Webb, R., J. Frank, and M. Raupp. 2003. Eastern hemlock recovery from hemlock woolly Adelgid following imidacloprid therapy. Journal of Arboriculture 29:298-302.

Joseph J. Doccola (corresponding author)

Director of Research

Arborjet, Inc.

99 Blueberry Hill Road

Woburn, Massachusetts 01801

joedoccola@arborjet.com

William Hascher

Arborist Manager

1 Approach Road

Biltmore Estate

Asheville, North Carolina 28803, U.S.

John Joseph Aiken

Arborjet, Inc.

46565 Garfield Road

Macomb, Michigan 48044 U.S.

Peter M. Wild

Arborjet, Inc.

99 Blueberry Hill Road

Woburn, Massachusetts 01801, U.S. 
Résumé. En raison de la présence généralisée du puceron lanigère de la pruche (Adelges tsugae Annand) au sein de l'habitat de la pruche du Canada (Tsuga canadensis Carrière), les arbres en milieu forestier peuvent être infestés plusieurs années avant qu'un traitement ne soit effectué. Les symptômes d'une infestation prolongée incluent un dépérissement généralisé et une couronne clairsemée. L'imidacloprid, un insecticide systémique neocotinoïde, s'avère un outil utile et efficace pour contrôler ce puceron. Dans cette étude, des arbres matures de gros calibre et en mauvaise condition ont été traités avec l'imidacloprid. Les arbres ont été traités une fois par injection dans le tronc ou le sol à Asheville en Caroline du Nord aux États-Unis. Suite à cette application, les variations en croissance de l'arbre, la densité en pucerons lanigères de la pruche et la présence résiduelle en imidacloprid ont été mesurées durant trois ans. Les arbres traités avec l'imidacloprid s'en sont sortis tandis que les arbres non traités continuaient d'en souffrir. Les arbres injectés avec l'imidacloprid présentaient une accumulation de ce composé chimique dans leur couronne, ce qui facilitait une reformation des aiguilles et la persistance de l'imidacloprid durant trois ans. Cette activité persistante de l'imidacloprid par injection dans le tronc a été attribuée en partie à son mouvement lent vers le haut au travers du système vasculaire restrictif en trachéides et à la capacité de rétention des aiguilles persistantes. L'imidacloprid par injection dans le sol a été plus lent dans son action systémique, mais il a présenté un plus grand potentiel en terme d'activité à long terme. Les chercheurs ont suggéré qu'une combinaison d'injections dans le sol et le tronc pouvant produire à la fois une action immédiate ainsi qu'une action à plus long terme (quatre ans et plus) constituerait une stratégie efficace et économique pour protéger les arbres de grande valeur.

Zusammenfassung. Wegen der weiten Verbreitung der HemlockWollschildlaus (Adelges tsugae Annand) (HWA) in den Quartieren der Östl. Hemlock-Tannen, können die Bäume in den Wäldern bereits viele Jahre vor der Behandlung infiziert worden sein. Die Symptome einer anhaltenden Infestation sind vornehmlich extensives Absterben und Ausdünnen von Kronenteilen. Imidacloprid, ein systemisches NeoNicotinoid-Insektizid, ist ein nützliches Mittel zur Bekämpfung und Kontrolle von HWA. In dieser Studie wurden ausgewachsene Bäume mit großem Stammumfang und bestehenden Kronenschäden mit Imidacloprid behandelt. In Ashville, Nord-Carolina wurden die Bäume einmal mit einer Stamm- oder Bodeninjektion behandelt. Nach der Behandlung wurden für drei Jahre die Veränderungen im Baum-Wachstum, die HWA-Dichte und die Rückstände des Insektizids gemessen. Die mit Imidacloprid behandelten Bäume erholten sich, währen die unbehandelten Bäume weiterhin litten. Die mit Imidacloprid behandelten Bäume entwickelten wieder dichte Kronen durch neue Benadelung und Imidacloprid blieb bis zu drei Jahren nachweisbar. Diese ausgedehnte Aktivität von Imidacloprid als StammInjektion wurde teilweise durch den langsamen Transport durch das enge vaskuläre Tracheiden-System und die andauernde Nadel-Retention beeinflusst. Die systemische Wirkung der Bodenbehandlung mit Imidacloprid war langsamer, aber hatte potentiell mehr Langzeitwirkung. Die Forscher schlagen eine Kombination von Baum - und Bodenbehandlung für sofortige und Langzeitwirkung (4+Jahre) als effektive und ökonomische Strategie zum Schutz von wertvollen Bäumen vor.
Resumen. Debido al amplio establecimiento del adelgido (Adelges tsugae Annand) (HWA) a través de un rango de abeto del Canadá (Tsuga canadensis Carrière), árboles maderables pueden ser infestados por muchos años antes de que se haga el tratamiento. Imidacloprid, un insecticida neonicotinoide, es una útil y efectiva herramienta para manejar HWA. En este estudio, árboles maduros de diámetro grande, en condición pobre, fueron tratados con imidacloprid. Los árboles fueron tratados una sola vez por inyección al tronco y/o suelo en Asheville, North Carolina, U. S. Después de la aplicación, se midieron por tres años los cambios en crecimiento del árbol, densidad de HWA y residuos de imidacloprid. Los árboles tratados con imidacloprid se recobraron, mientras que los árboles no tratados continuaron con problemas. Los árboles inyectados con imidacloprid acumularon el compuesto en la copa, facilitando la refoliación y el imidacloprid persistió por tres años. Esta extendida actividad del imidacloprid inyectado al tronco fue atribuida en parte al lento movimiento ascendente a través del restrictivo sistema vascular de las traqueidas y a la retención perenne de las agujas. La inyección al suelo de imidacloprid fue más lenta para actuar sistemáticamente, pero tiene potencial para actuar a largo plazo. Los investigadores sugieren la combinación de inyección al árbol y al suelo para una actividad inmediata y a largo término (4+ años) como una efectiva y económica estrategia para proteger árboles valiosos. 